AperTO - Archivio Istituzionale Open Access dell'Università di Torino

\title{
Molecular biomarkers to predict response to neoadjuvant chemotherapy for bladder cancer
}

\section{This is the author's manuscript}

Original Citation:

Availability:

This version is available http://hdl.handle.net/2318/1623655

since 2019-02-07T11:26:24Z

Published version:

DOI:10.1016/j.ctrv.2017.01.002

Terms of use:

Open Access

Anyone can freely access the full text of works made available as "Open Access". Works made available under a Creative Commons license can be used according to the terms and conditions of said license. Use of all other works requires consent of the right holder (author or publisher) if not exempted from copyright protection by the applicable law. 
This Accepted Author Manuscript (AAM) is copyrighted and published by Elsevier. It is posted here by agreement between Elsevier and the University of Turin. Changes resulting from the publishing process - such as editing, corrections, structural formatting, and other quality control mechanisms - may not be reflected in this version of the text. The definitive version of the text was subsequently published in CANCER TREATMENT REVIEWS, 54, 2017, 10.1016/j.ctrv.2017.01.002.

You may download, copy and otherwise use the AAM for non-commercial purposes provided that your license is limited by the following restrictions:

(1) You may use this AAM for non-commercial purposes only under the terms of the CC-BY-NC-ND license.

(2) The integrity of the work and identification of the author, copyright owner, and publisher must be preserved in any copy.

(3) You must attribute this AAM in the following format: Creative Commons BY-NC-ND license (http://creativecommons.org/licenses/by-nc-nd/4.0/deed.en), 10.1016/j.ctrv.2017.01.002

The publisher's version is available at:

http://linkinghub.elsevier.com/retrieve/pii/S0305737217300026

When citing, please refer to the published version.

Link to this full text:

http://hdl.handle.net/2318/1623655 
Manuscript Number: CTR-D-16-00429R1

Title: Molecular biomarkers to predict response to neoadjuvant chemotherapy for bladder cancer

Article Type: Review Article

Section/Category: Tumour Review

Keywords: Bladder cancer, urothelial carcinoma, neoadjuvant chemotherapy, biomarkers, resistance, sensitivity.

Corresponding Author: Professor Giorgio Scagliotti, MD, PhD

Corresponding Author's Institution: University of Turin

First Author: Consuelo Buttigliero, MD

Order of Authors: Consuelo Buttigliero, MD; Marcello Tucci, MD; Francesca Vignani, MD; Giorgio Scagliotti, MD, PhD; Massimo Di Maio, MD, PhD

Abstract: Cystectomy is the gold standard for treatment of localized muscle-invasive bladder cancer. However, about 50\% of patients develop metastases within 2 years after cystectomy and subsequently die for the disease. Neoadjuvant cisplatin-based chemotherapy before cystectomy improves the overall survival in patients with muscle-invasive bladder cancer, and pathological response to neoadjuvant treatment (downstaging to spT1 at cystectomy) is a strong predictor of better disease-specific survival. Nevertheless, some patients do not benefit from neoadjuvant therapy. The identification of reliable biomarkers that could enable the clinicians to identify patients who will really benefit from neoadjuvant chemotherapy is a major issue. This approach could lead to individualized therapy, in order to optimize the chance of response, avoiding the impact of neoadjuvant treatment on quality of life and the delay of cystectomy in non-responder patients. However, no molecular predictive biomarkers have shown clinical utility.

This paper aims to review currently available data about biomarkers predictive of response to neoadjuvant chemotherapy in muscle-invasive bladder cancer.

Suggested Reviewers: Francesco Massari University of Verona

fmassari79@gmail.com

Giuseppe Fornarini

IRCCS Azienda Ospedaliero Universitaria San Martino, Genova Italy giuseppe.fornarini@hsanmartino.it

Franco Morelli

Medical Oncology Department, Casa Sollievo della Sofferenza, San Giovanni Rotondo, Italy

oncologia@operapadrepio.it 

Dear editor,

Here attached please find the revised manuscript entitled "Molecular biomarkers to predict response to neoadjuvant chemotherapy for bladder cancer" by Buttigliero et al. that we wish to resubmit for publication as an original paper to Cancer Treatment Reviews.

As itemized in the attached point by point response to reviewers, all reviewers comment and criticisms were carefully taken into account in preparing the new manuscript version.

Looking forward to the decision of the Editorial Office, we remain.

Yours sincerely

Giorgio V. Scagliotti

On behalf of all co-authors 


\section{$\underline{\text { Response to reviewers }}$}

Reviewer 2

Major Comments:

- Page 8: More data on ERCC2 was published in JAMA earlier this year (PubMed PMID: 27310333) and should be included in the discussion of ERCC2. Should be added to table 1 also.

We thank the Reviewer for the suggestion. We added the data about ERCC2 published by Liu D. et al in JAMA 2016, both in the text and in Table 1.

- Page 8. The ATM, RB and FANCC signature is discussed under the heading gene expression signatures. This signature is a genomic DNA repair defect signature based on alterations determined by sequencing. Recommend either discussing this in the DNA damage repair section of the manuscript or editing the subtitle to convey the nature of the signature.

As suggested, we moved the date about ATM, RB and FANCC signature from the section "gene expression signature" to the section "DNA damage repair".

- P 10 "The combination of GDPD3 and SPRED1 resulted in a multivariate classification tree that was significantly associated with the chance of obtaining a response to NC." - please provided stats including $\mathrm{p}$ values to be consistent with the rest of the paper.

We added the statistical test previously not reported (Goodman-Kruskal $v=0.85 p<0.0001$ ).

- $p .10$ the discussion of the Williams et al Cancer research paper is not clear and somewhat misleading. That paper from 2009 discusses a GEM score generated from $\mathrm{NCl}-60$ cell lines and then validated using data obtained from human tumor tissue samples from bladder 59 cancer patients.

We thank the Reviewer for this comment. The sentence has been modified as follows: "Williams et al. validated a GEM score based on in vitro drug sensitivities and microarray analyses of a NCl-60 cancer cell line panel, using data obtained from human tumor tissue samples from 59 bladder, 143 ovarian and 275 breast cancer patients treated with chemotherapy. In bladder cancer patients treated with neoadjuvant methotrexate, vinblastine, adriamycin and cisplatin, the 3-year os for those with favorable gene expression model scores was $81 \%$, versus $33 \%$ for those with less favourable scores $(p=0.002)$.

- The bibliography may be formatted to journal specifications, but several of the references are abstracts and this isn't clear as they are listed (example refs 33, and 34).

We thank the Reviewer for the remark. We checked the bibliography carefully.

- The subtypes defined in the Choi paper are discussed on page 10-11. These signatures are from gene expression data, not sequencing. Recommend expanding on the data linking these subtypes with chemotherapy sensitivity and resistance.

As suggested, we highlighted that the subtypes proposed by Choi et al are from gene expression data and we expanded the paragraph about relationship of these subtypes with chemotherapy sensitivity and resistance. 
- $\quad$ p.15 it is not clear why the TCGA driver mutations and targeted therapies are highlighted in the discussion session. These sections do not relate to the data presented nor to this section of the text

We agree with the Reviewer that some topics (TCGA, targeted therapies) are currently not directly related to the object of our review. However, in the Discussion, we discussed some topics that will be probably relevant in the near future. In detail, we placed the paragraph about the TCGA in the Discussion, because we wanted to emphasize, among the final messages of the paper, that further studies of histopathological and molecular features of each TCGA subtype are strongly needed, to improve our understanding of mechanisms that underlie treatment response or resistance. Similarly, another message that we wanted to emphasize is the modest activity obtained in bladder cancer with most targeted therapies, underlying, even with these drugs, the complexity of mechanisms of resistance, and the need of better selecting patients.

- P 16 Would end on a more forward-looking note rather than repeat text from the opening paragraph "Validate predictive biomarkers of response to NC are currently lacking for MIBC." Furthermore that sentence is not technically true as both ERCC2 and the ATM/RB1 FANCC signatures were validated in independent datasets.

We have replaced the sentence with: "Many efforts have been and are continuing to be made to identify and validate predictive biomarkers of response to NC."

- Highlights bullet points have many typos and state "Genetic and molecular features can help to identify patients likely to benefit from NC" - but the in the body of the text the authors make the point that "Validate predictive biomarkers of response to NC are currently lacking."

As suggested we revised the highlights bullet point.

- Suggest adding the Choi subtypes to Table 1, there is enrichment for response in some subsets vs others as described in the text

We thank the Reviewer for the suggestion. We added the Choi sybtype to table 1.

Minor comments:

- Consider grouping discussion of micro-environment related molecules and targeted/immunotherapies together as future directions since there is no data related to neoadjuvant outcomes with these molecules/agents.

As the reviewer suggested we grouped discussion of micro-environment related molecules and targeted/immunotherapies together as future directions.

- Typo on page 7 "immunoistochemical expression of ERCC1 and PR (pT0)" - should be pCR. We corrected the acronym $P R$.

- P 7: GCGS - acronym not previously defined We corrected the acronym GC (gemcitabine and cisplatin) 
- P13 - revise for clarity "The standard of care for MIBC should combine cisplatin-based chemotherapy followed by radical cystectomy with extended pelvic lymph (node) dissection."

We revised the sentence.

- P 14 - Unfortunately these biomarkers cannot (yet?) be used to select patients who benefit from NC.

As suggested we inserted "yet" in the sentence. 


\section{Molecular biomarkers to predict response to neoadjuvant chemotherapy for bladder cancer}

Consuelo Buttigliero $^{1 *}$, Marcello Tucci ${ }^{1 *}$, Francesca Vignani ${ }^{1 \S}$, Giorgio V. Scagliotti ${ }^{1}$, Massimo Di Maio ${ }^{1 \S}$.

* These Authors contributed equally to the paper

1Division of Medical Oncology, Department of Oncology, University of Turin, San Luigi Gonzaga Hospital, Regione Gonzole 10, 10043 Orbassano, Turin, Italy

§present address: Division of Medical Oncology, Ordine Mauriziano Hospital, Via Magellano 1, 10028 Turin, Italy

Correponding author

Prof. Giorgio Vittorio Scagliotti

Department of Oncology, University of Turin, San Luigi Gonzaga Hospital, Regione Gonzole 10, 10043 Orbassano (Turin), Italy.

Phone: +390119026414

Fax: +390119015184

E-mail: giorgio.scagliotti@unito.it 


\title{
Molecular biomarkers to predict response to neoadjuvant chemotherapy for bladder cancer
}

\begin{abstract}
Cystectomy is the gold standard for treatment of localized muscle-invasive bladder cancer. However, about $50 \%$ of patients develop metastases within 2 years after cystectomy and subsequently die for the disease. Neoadjuvant cisplatin-based chemotherapy before cystectomy improves the overall survival in patients with muscle-invasive bladder cancer, and pathological response to neoadjuvant treatment (downstaging to $\leq \mathrm{pT} 1$ at cystectomy) is a strong predictor of better disease-specific survival. Nevertheless, some patients do not benefit from neoadjuvant therapy. The identification of reliable biomarkers that could enable the clinicians to identify patients who will really benefit from neoadjuvant chemotherapy is a major issue. This approach could lead to individualized therapy, in order to optimize the chance of response, avoiding the impact of neoadjuvant treatment on quality of life and the delay of cystectomy in non-responder patients. However, no molecular predictive biomarkers have shown clinical utility.

This paper aims to review currently available data about biomarkers predictive of response to neoadjuvant chemotherapy in muscle-invasive bladder cancer.
\end{abstract}

\section{Running title}

Predictive biomarkers in bladder cancer neoadjuvant chemotherapy

\section{Keywords}

Bladder cancer, urothelial carcinoma, neoadjuvant chemotherapy, biomarkers, resistance, sensitivity. 


\section{Introduction}

Bladder cancer (BC) is usually diagnosed at a surgically resectable stage, and early radical cystectomy with pelvic node dissection remains the cornerstone of therapy of muscle-invasive disease. However, cancer-specific survival after cystectomy is relatively low, ranging from $72 \%$ at 5 years for patients with organ-confined disease, to $48-25 \%$ at 5 years in patients with extravescical extension or lymph node metastases. Nearly half of patients diagnosed with stages T2b-T4a develop metastatic disease within two years [1].

The low cure rates with radical cystectomy imply that, in many cases, muscle-invasive bladder cancer (MIBC) is ab initio a micro-metastatic disease. This supports the use of perioperative systemic treatment, to achieve a better disease control and improve survival. In fact, the rationale of neoadjuvant treatment is the early eradication of micro-metastases, combined to a downstaging of the primary tumor in patients with clinical stage T2-T4a NO MO MIBC, candidates for definitive surgery or radiation. Furthermore, neoadjuvant treatment is better tolerated than chemotherapy after surgery, due to the relevant post-cystectomy morbidity. Finally, using neoadjuvant therapy, activity of systemic treatment can be tested in vivo, obtaining important prognostic data.

The literature clearly supports neoadjuvant chemotherapy (NC), demonstrating a $5-10 \%$ increase in 5-year cancer-specific survival in MIBC compared with surgery alone. Interestingly, the 5-year cancer-specific survival for responders to NC (<ypT2) is $90 \%$, in contrast to the $30-40 \%$ for those not obtaining an objective response. Conversely, data supporting adjuvant chemotherapy are less robust. Yet, despite level-one evidence $[2,3]$, neoadjuvant cisplatin-based chemotherapy met resistance in medical communities around the world [4], mainly due to the concerns related to the disappointing delay of surgery in non-responders patients, the potential toxicity, and the inability to predict the chance of response.

However, to date, no method exists for predicting response to NC, and some patients will suffer from its toxicity, without achieving any benefit. Furthermore, due to a deterioration in their physical conditions possibly associated with the absence of activity of neoadjuvant treatment, some patients will lose the opportunity for additional, alternative therapy. Hence, the ability to identify patients who would really benefit from NC is a major clinical issue.

The aim of this review is to summarize and discuss currently available data about biomarkers tested as predictive factors of response to NC in MIBC. 


\section{Neoadjuvant cisplatin-based chemotherapy for bladder cancer}

Two large, randomized trials $[5,6]$ and two meta-analyses $[7,8]$ showed that NC provides survival benefit compared with surgery alone in patients with MIBC. In the SWOG 8710 randomized trial [5], 317 patients with operable clinical T2-T4, NO MO disease were assigned to receive three cycles of NC with methotrexate, vinblastine, doxorubicin and cisplatin (MVAC) followed by cystectomy, or cystectomy alone. The study was designed with overall survival (OS) as primary endpoint. OS was longer in patients assigned to chemotherapy (median 77 vs. 46 months), although this difference did not reach the threshold of statistical significance $(p=0.06)$. Neoadjuvant MVAC yielded a significantly higher $\mathrm{pCR}$ rate $(38 \%$ vs $15 \%, \mathrm{p}<0.001)$, which was associated with a significant higher 5-year survival (85\%).

In the International Collaboration of Trialists study [6] 976 patients with clinical T2 grade 3, T3 or T4a, node negative bladder cancer were randomized to receive 3 cycles of neoadjuvant cisplatin, methotrexate, and vinblastine (CMV) or no chemotherapy before local treatment (radical cystectomy or radiation). NC demonstrated a statistically significant $16 \%$ reduction in the risk of death (HR 0.84; 95\% $\mathrm{Cl} 0.72-0.99, \mathrm{p}=0.037)$, corresponding to an increase in 10-year survival from $30 \%$ to $36 \%$ with neoadjuvant treatment. In the subgroup of 428 patients who underwent cystectomy, pCR was higher in the chemotherapy arm (32 vs 12\%)[9].

Two main meta-analyses have been performed $[7,8]$, both showing a significant survival benefit associated with NC. In the first one [7], based on individual data of 3005 patients from 11 trials, the 5-year survival improved from 45 to $50 \%$, with a $14 \%$ reduction in the risk of death (HR: 0.86 ; $95 \% \mathrm{Cl}$ 0.77-0.95, $\mathrm{p}=0.02$ ) for patients assigned to NC.

Based on this evidence, NC has been recommended by consensus guidelines in both the United States and Europe [2, 3].

In 2000, similar efficacy but improved toxicity was reported with gemcitabine and cisplatin (GC) compared with standard MVAC in patients with metastatic BC [10]. This experience in advanced disease has been extrapolated to the neoadjuvant setting; thus, 3-4 cycles of GC are frequently used as neoadjuvant treatment [11], although this combination has never been prospectively evaluated [12].

Two multicentre prospective trials tested modifications of the classical MVAC regimen to either accelerated MVAC [13] or dose-dense MVAC [14]. Both studies treated approximately 40 patients with 3-4 cycles of modified MVAC. In the first study [13], accelerated MVAC obtained pCR in 38\% of patients, in the second one $49 \%$ of patients achieved a pathological response, defined by 
pathological downstaging $\leq \mathrm{pT} 1$, after dose-dense MVAC [14]. These studies demonstrated that modified MVAC regimen considerably reduced time to surgery, with an acceptable safety profile, and showed that toxicity did not preclude subsequent surgery.

Based on the available data CMV, MVAC and GC combinations can be used in the neoadjuvant setting.

In summary, early eradication of micro-metastases combined to a down-staging of the primary tumour, and its significant impact on survival are the strengths of NC, which also provides a better toxicity profile, compared to adjuvant chemotherapy. Potential disadvantages of NC include less accurate staging, possible increased surgical morbidity and mortality, and delay in curative surgery. Moreover, patients with disease progression during NC will not benefit from surgery.

\section{Biomarkers predictive of response to neoadjuvant chemotherapy for muscle- invasive bladder cancer.}

Multiple molecular biomarkers have been studied for prediction of response to NC, including: regulators of apoptosis and cell survival, pathways involved in DNA repair, receptor tyrosine kinases, gene expression patterns, cellular mechanisms of drug uptake and transport, microenvironment-related molecules (Table 1).

\section{Regulators of apoptosis and cell survival.}

p53 acts as a tumor suppressor gene, able to respond to DNA damage, inducing cell cycle arrest and regulating cell survival and apoptosis.

Alterations in the p53 gene have been reported in about $50 \%$ of bladder cancers, correlated with high grade and advanced stage [15]. Mutant p53 protein is usually overexpressed, due to increased stability compared to wildtype product. In vitro, most p53 mutations confer sensitivity to cisplatin and doxorubicin in bladder cancer cells [16]. However, there are conflicting data about the relationship between chemosensitivity and $\mathrm{p} 53$.

In a phase II trial testing accelerated MVAC as neoadjuvant treatment, Plimack and colleagues analysed molecular alterations in baseline tumour samples [13]. No correlation was demonstrated between p53 deleterious mutations and response to chemotherapy[13]. A further study reported that p53 immunoreactivity did not predict response to preoperative systemic chemotherapy in patients with invasive urothelial carcinoma [17]. 
Several studies in patients undergoing NC MVAC demonstrated a correlation between p53 overexpression at immunohistochemistry and poor outcome [18-20]. On the contrary, Watanabe et al. [21] demonstrated that wild-type p53, investigated with cDNA sequencing, was related to a poor response to systemic chemotherapy in a series of surgically treated urothelial tumor specimens.

The proteins of $\mathrm{Bcl}-2$ family are implicated in the response of cells to apoptotic stimuli.

$\mathrm{Bcl}-2$ is an anti-apoptotic protein, that has been shown as a predictive marker to either chemotherapy or radiotherapy in advanced bladder cancer [22, 23].

Cooke and collaborators randomized 51 patients with MIBC to radiotherapy or radiotherapy plus neoadjuvant cisplatin. The study did not demonstrate a prognostic role of $\mathrm{Bcl}-2$ positivity in the overall study population but, when only the subgroup of patients who received cisplatin [24] was considered, $\mathrm{Bcl}-2$ negative patients had a median survival of 72 months compared with 17 months of $\mathrm{Bcl}-2$ positive patients ( $\mathrm{p}<0.03$ ); the 5 -year survival rate was respectively $55 \%$ and $14 \%$. Authors suggested that the determination of $\mathrm{Bcl}-2$ status in patients undergoing radiotherapy for MIBC could help to identify those who may benefit from neoadjuvant chemotherapy.

\section{Pathways involved in DNA repair.}

The breast cancer susceptibility gene 1 (BRCA1) codifies for a nuclear protein, involved in biological processes related to response to therapeutic DNA damage. Low BRCA1 levels are associated with sensitivity to cisplatin [25]. In order to investigate the predictive role of BRCA1 mRNA expression in BC, tumor samples of 57 bladder cancer patients treated with NC (CMV or gemcitabine and cisplatin) were retrospectively analysed using quantitative polymerase chain reaction [26]. Patients were divided into terciles according to BRCA1 levels. Sixty-six percent of patients with low/intermediate BRCA1 levels attained a PR, defined as PTO-T1, compared to $22 \%$ of those with high levels. Furthermore, median survival was longer in patients with low BRCA1 expression (168 versus 34 months, $\mathrm{p}=0.002$ ). In multivariate analysis, only lympho-vascular invasion and BRCA1 mRNA expression levels (HR: $2.73,95 \% \mathrm{Cl}: 1.16-6.39, \mathrm{p}=0.02$ ) emerged as independent prognostic factors of overall survival. However, these results have not been validated in an external series .

Other genes involved in DNA repair (ERCC1 and RRM1) or in drug resistance (MDR1 and caveolin-1) have been assessed as potential predictive or prognostic markers in the adjuvant or metastatic setting, suggesting a possible role for MDR1 and ERCC1 [27, 28]. 
The cytotoxic effect of platinum-based chemotherapy has been attributed to the formation of bulky platinum DNA adducts. Cisplatin resistance seems to be associated with the removal of these DNA adducts by the nucleotide excision repair (NER) system, a highly conserved DNA repair system. Excision repair cross complementing 1 (ERCC1) is the lead enzyme in NER process, and its role as a predictor of platinum sensitivity was initially highlighted in a study of patients with radically resected non-small-cell lung cancer treated with cisplatin-based adjuvant chemotherapy [29]. ERCC1-negative tumors seemed to benefit from cisplatin-based chemotherapy, whereas patients with ERCC1-positive tumors did not. In bladder cancer, in the trial testing dose-dense MVAC NC, Choueiri et al. [14] tested, as secondary endpoint, the relationship between immunoistochemical expression of ERCC1 and PCR (pTO). Of the 31 patients enrolled in the study with adequate pre-treatment tumor specimens, 12 patients (39\%) were classified as ERCC1 positive. With the clear limitation of the small sample size, no significant association between ERCC1 positivity and PCR was detected. In detail, $43 \%$ of ERCC1-positive and $60 \%$ of ERCC1negative patients achieved $\mathrm{pCR}$.

Conversely, in a retrospective study, low levels of ERCC1 mRNA, determined by RT-PCR in tumor DNA from 57 advanced and metastatic bladder cancer patients treated with either GC or gemcitabine, cisplatin and paclitaxel, were associated with a significantly longer survival (median 24.5 versus 15.4 months; $p=0.03$ ) and longer time to disease progression, although the difference in the latter endpoint did not reach statistical significance [27]. On multivariate analyses with pretreatment prognostic factors, ERCC1 emerged as an independent predictive factor of survival. A longer time to progression, although not statistically significant, was also observed in patients with low levels of ribonucleotide reductase subunit M1 (RRM1), BRCA1 and caveolin-1. However, a clear link between the expression of these four markers and response to chemotherapy has not been established.

ERCC2, a nucleotide excision repair gene, is another leading actor in the NER system. In a retrospective study [30], the authors performed whole exome sequencing on pre-treatment tumor from 50 patients with muscle invasive urothelial carcinoma who received neoadjuvant cisplatinbased chemotherapy. Comparing the profile of cisplatin responders (TO/Tis) with non-responders $(\geq \mathrm{pT} 2)$, ERCC2 was the only mutated gene significantly enriched in the cisplatin responders. While ERCC2 mutations occur in approximately $12 \%$ of unselected cases, $36 \%$ of responders harboured somatic, non synonymous mutations of ERCC2. Moreover, all ERCC2 mutant tumors responded to 
NC, suggesting that ERCC2 mutations result in loss of normal ERCC2 function, leading to increased tumor cell sensitivity to DNA-damaging agents such as cisplatin.

A subsequent study confirmed that ERCC2 missense mutations were more common in NC complete responders to cisplatin-based NC, but this association did not reach statistical significance: 6 somatic ERCC2 missense mutation were identified in 38 complete responders (16\%) and 2 in 33 non-responders (6\%; $p=0.27)$ [31].

In a more recent study Liu et al. [32] investigated the association of ERCC2 somatic mutations and pathological response to cisplatin-based NC in 62 patients with MIBC from 2 clinical trial of NC who completed 3 cycles of chemotherapy. Among 48 patients included in the analysis $40 \%$ of responders and 7\% of non-responders had a non-synonimous ERCC2 genetic alteration (odds ratio: 8.3; 95\% Cl: 1.4-91.4; $\mathrm{p}=0.01)$. There was a statistically significant difference in OS among patients with compared to those without ERCC2 alterations $(p=0.03)$.

Recently, lyer et al. investigated the relationship between alterations in a DNA damage repair (DDR) gene set and response to NC in 46 patients enrolled in a phase II study [33] of neoadjuvant dose-dense GC. The most frequently altered DDR genes were BRCA2 and ATR (12\% each). The median number of DDR alterations in responders vs non-responders was similar (1 vs 2); however, 5 of 14 responders had deleterious DDR alterations vs 0 of 10 non-responders $(p=0.053)$.[34]

In a prospective study [35], Plimack et al. demonstrated that genomic alterations in DNA repairassociated genes ATM, RB and FANCC predict response and clinical benefit after cisplatin-based NC for MIBC, confirming that defective DNA repair can increase tumour sensitivity to cisplatin. DNA obtained from a discovery set of prospectively collected pre-treatment tumour samples from patients treated in the trial testing accelerated MVAC [13], was sequenced for all coding exons of 287 cancer-related genes and was analysed for base substitutions, copy number alterations and selected rearrangements. A set of identically collected samples from a follow-up trial of similar design testing 3 cycles of neoadjuvant dose-dense GC chemotherapy [36] was used as validation cohort. Patients with $\mathrm{PCR}$ had more alterations than those with residual tumor in both the discovery $(p=0.024)$ and validation $(p=0.018)$ cohort. In the discovery set, alterations in ATM, RB1 or FANCC predict pathologic response ( $p<0.001,87 \%$ sensitivity, $100 \%$ specificity) and better OS ( $p=0.007)$ (Table 1).

\section{Receptor tyrosine kinases.}


ERBB2 is an orphan receptor, member of the epidermal growth factor receptor family, without a known, specific ligand. ERBB2 is over-expressed in many tumors, and showed to correlate with tumor recurrence and metastases development in BC [37].

In a recent study, 9 of 38 complete responders (ypTONO) to cisplatin-based NC had ERBB2 missense mutations, whereas none of 33 non-responders (higher than ypT2) had ERBB2 mutations ( $p=0.003$ ) [31].

\section{Gene expression signatures: gene expression models predictive of response to NC.}

Profiling of gene expression patterns on genome-wide cDNA microarrays is another useful approach to identify molecules related to response to anticancer drugs.

Takata et al. analysed biopsy materials from 18 transitional cell BC patients using a cDNA microarray including 27648 genes. Patients who achieved pathological ( $\leq \mathrm{pT} 1)$ or radiological ( $\leq \mathrm{cT} 1)$ downstaging after 2 cycles of MVAC NC, were classified as responders. Fourteen genes separated the responders from non-responders and allowed the determination of a numerical prediction scoring system [38]. Among those genes, topoisomerase 2a, a target of doxorubicin, was downregulated in non-responders. Subsequently, the investigators externally validated these findings in a small dataset [39]. This scoring system correctly predicted response for 8 out of 9 test cases in the first report [38], and for 19 out of 22 test cases in the second report [39]. However, these analyses are limited by the modality of response assessment (imaging only at least in some patients) and obviously by the small number of patients.

Kato and colleagues [40] analysed gene expression profiles in biopsy samples from 37 patients with advanced BC, using a microarray of 38500 genes, to establish a method for predicting response to NC with carboplatin and gemcitabine. They found 12 genes significantly differentially expressed between responders and non-responders, and established a numerical prediction scoring system clearly separating the two groups. Among those 12 predictive genes, IPO7, encoding for a protein that imports proteins into the nucleus acting as an adapter-like protein, was up-regulated in the non-responders and probably contribute to resistance through inhibiting caspase- 3 activity, as previously described in ovarian cancer cells [41, 42]. Furthermore, solute-carrier family 22, member 18 (SLC22A18), encoding for an organic cation transporter, that belongs to the polyspecific transporter/multi-drug resistance gene family, was up-regulated in non-responders. Pharmacogenomic studies suggest that SLC22A18 could be a transporter of gemcitabine [43]. Hence, SLC22A18 up-regulated expression may contribute to resistance to gemcitabine. 
Messenger-RNA expression data from the report of Kato and colleagues were subsequently reanalyzed in conjunction with the antibody dataset of the Human Protein Atlas, in order to identify candidate protein biomarkers detectable by immunohistochemistry [44]. The authors identified 8 candidate protein biomarkers, that were tested in tissue microarrays derived from baseline biopsies of 37 patients, subsequently treated with CG NC and cystectomy.

The combination of GDPD3 and SPRED1 resulted in a multivariate classification tree that was significantly associated with the chance of obtaining a response to NC (Goodman-Kruskal $\gamma=0.85$ $\mathrm{p}<0.0001$ ). Also clinical factors, such as age $>60$ at cystectomy and clinical stage $>c T 2$, were independent factors significantly associated with NC resistance. The authors proposed two independent models, the first based on clinical factors and the second based on protein markers, and both models were strongly associated with the prediction of resistance to NC. Finally, the combination of the two models resulted in a prediction model able to significantly stratify the likelihood of NC resistance in the tested cohort $(n=37)$ into two well separated groups $(p=0.0002)$ : low $(26 \%, n=19)$ and high $(89 \%, n=18)$.

All these gene expression models are developed using a training microarray set from tumors of patients with known clinical responses. Although validation is straightforward, it can be long and expensive, requiring human tumor tissue from patients treated with the specific drug regimen used in patients included in the training set. Moreover, this approach does not permit prediction of responses to drugs not used in the model development. To overcome these limitations, Williams et al. [45] validated a GEM score based on in vitro drug sensitivities and microarray analyses of a NCI60 cancer cell line panel, using data obtained from human tumor tissue samples from 59 bladder, 143 ovarian and 275 breast cancer patients treated with chemotherapy [46-48]. In bladder cancer patients treated with neoadjuvant methotrexate, vinblastine, adriamycin and cisplatin, the 3-year OS for those with favorable gene expression model scores was $81 \%$, versus $33 \%$ for those with less favourable scores $(p=0.002)$. Studies developing gene expression models predictive of response to NC are shown in Table 1.

In 2014, the South-west Oncology Group (SWOG) launched a neoadjuvant trial (NCT02177695), currently recruiting, in MIBC patients, to compare the efficacy of the two frontline chemotherapy regimens (GC versus MVAC) and the ability of a gene expression profiling-based algorithm, called CoXEN, to predict cPR [49].

Molecular subtypes of bladder cancer: emerging targets and biomarkers of treatment. 
Recent studies integrating genomic data from gene expression array, targeted mutation sequencing analyses and protein analyses, defined clinically relevant molecular subtypes of bladder cancer. Lindgren et al. [50] first recognized the worse prognosis associated with a gene expression profile of a keratinized/squamous phenotype. This molecular subtype, termed "basal like", and characterized by p63 activation, squamous differentiation, positive CK5/6, EGFR, and cluster of differentiation (CD)44 expression and lack of cytokeratin (CK)20, was further validated by Choi [51], who used whole genome mRNA expression profiling to identify 3 distinct subtypes of MIBC: "basal like", "luminal like" and "p53-like". Basal tumors were characterized by squamous differentiation and were associated with shorter disease-specific and overall survival, but responded to NC, as do some basal breast cancers. Hence, early management of "basal like" MIBCs with NC could offer to these patients the best chance for improved survival for patients with this potentially deadly form of disease. Luminal subtype" were characterized by active PPARy and estrogen receptor (ER) transcription and enriched with activating FGFR3 mutations. Therefore, the authors suggested that agents targeting ER, ERBB2/3, PPARy or FGFR, may be clinically active in this subtype of MIBC. Since several "luminal" MIBC responded to NC, these targeted therapies should probably be tested in combination with conventional chemotherapy. "P53-like" MIBC subtype is characterized by wildtype TP53 expression. The authors observed that all of the p53-like MIBCs from patients treated with NC in the discovery cohort $(n=7)$ were resistant to chemotherapy. To further probe this relationship, they explored the chemo resistance of p53-like MIBCs in an expanded NC cohort $(n=$ 34) and in an additional cohort of 23 archival tumors of patients treated with MVAC in a phase III trial. They found that p53-like MIBCs in both cohorts were resistant to NC. They finally demonstrated that, upon resistance to chemotherapy, tumors originally classified as "basal-like" and "luminal" subtypes also shifted to a "p53-like" phenotype.

\section{Cellular mechanisms of drug uptake and transport.}

Copper transporter receptor 1 (CTR1) plays an important role in platinum uptake, and a recent study demonstrated a correlation between CTR1 tumor expression and pathological outcome in 47 MIBC patients treated with neoadjuvant cisplatin-based chemotherapy $(p=0.0076$ in pre-treatment specimens and $p=0.023$ in post-treatment specimens) [52].

Reports on P-glycoprotein [53] in tumor specimens of metastatic urothelial carcinoma suggested that this factor might predict resistance to chemotherapy and risk of treatment toxicity. Pglycoprotein expression (the product of the multidrug resistance gene, MDR-1) has been studied in 
pre- and post-chemotherapy fresh frozen tissue sections of primary and metastatic urothelial tumours of patients treated with MVAC showing an increase in the proportion of cells expressing Pglycoprotein after exposure to chemotherapy [53]. The role of P-glycoprotein has never been specifically investigated in neoadjuvant setting.

\section{Future directions}

Also the role of microenvironment-related molecules has been studied in urothelial $\mathrm{BC}$, to define their potential impact on cisplatin resistance. Afonso et al. [54] investigated the clinicalpathological and prognostic significance of the monocarboxylate transporters (MCT) 1, MCT4, CD147, CD44 and carbonic anhydrase IX (CAIX) in a cohort of 114 patients with urothelial BC who underwent transurethral resection and/or cystectomy. The presence of MTC1, MTC4 and/or CD147 was associated with unfavourable prognosis. Moreover, when selecting patients who received cisplatin, prognosis was significantly worse in those with MTC1 and CD147 positive tumors. CD147 specific silencing by small interfering RNAs (siRNA) in urothelial bladder cancer cells resulted in an increase in chemosensitivity to cisplatin. Similar results were obtained in advanced bladder cancer, where CD147 expression was related to response to cisplatin-containig regimens [55].

Elevation of glutathione, a tripeptide that conjugates with many electrophiles (including some cytotoxic agents), has been widely demonstrated in cells resistant to platinum complexes and alkylating agents [56]. In vitro higher level of glutathione were found in transitional cell carcinoma compared to tumor-free bladder tissue and in nontumor bladder tissue from patients with bladder cancer than from patients without transitional cell carcinoma [57].

Siu et al. investigated the prognostic role of metallothionein in tissue from primary tumors of 118 patients with urothelial cancer subsequently treated with cisplatin-based chemotherapy. Overexpression of metallothionein was associated with poorer outcome, possibly due to cisplatin resistance [58]. However, the impact of glutathione and metalloproteinase expression has never been studied in patients treated with NC.

Finally, several clinical trials testing targeted therapies and immunotherapies in the neoadjuvant setting for MIBC have been performed.

Two studies tested bevacizumab in combination with chemotherapy (GC and dose-dense MVAC), showing a pathologic response rate of 31 and 53\% respectively $[59,60]$. Two studies that investigated sunitinib with chemotherapy in neoadjuvant setting were stopped early due to toxicity 
$[61,62]$. Other two studies tested the efficacy of tyrosine kinase inhibitors, erlotinib [63] and dasatinib [64], reporting pathological response rates of 35 and $14 \%$ respectively.

A phase II trial of Lapatinib in association to GC as neoadjuvant therapy in MIBC, was terminated early due to toxicity [65].

To date, however, there are no biomarkers predictive of response to targeted therapies, neither in the neoadjuvant setting nor in the advanced disease.

A phase 1-2 trial is currently testing the combination of chemotherapy (GC) with ALT-801, an innovative immunotherapeutic fusion protein consisting of interleukin-2 (IL-2), linked to a single chain T cell receptor domain (SCTCR), developed to target cancer cells that overexpress the tumorassociated antigen p53, in neoadjuvant setting (NTC01326871).

A small study investigated the immunologic effects of Ipilimumab in 12 patients with localized bladder urothelial carcinoma before surgery. All patients had an increased frequency of $\mathrm{CD}^{+}{ }^{+} \mathrm{COS}^{\text {hi }} \mathrm{T}$ cells in the systemic circulation and tumor tissues, that has been shown to correlate with OS improvement in melanoma [66].

Another ongoing trial evaluates neoadjuvant pembrolizumab in combination with GC in patients with T2-4a NO MO urothelial cancer (NCT02365766).

In addition, immunotherapy is under study in the neoadjuvant setting within a phase II study with atezolizumab, an anti-PD-L1 antibody, administered to subjects with either BCG-refractory nonMIBC, or MIBC appropriate for cystectomy and refusing or ineligible for neoadjuvant chemotherapy (NCT02451423).

If immunotherapy would be confirmed to be effective in neoadjuvant setting, it will require the identification of biomarkers predictive of response. In the phase II trial testing atezolizumab in 310 patients with locally advanced and metastatic urothelial carcinoma after treatment with platinumbased chemotherapy, the percentage of PD-L1 positive immune cell (ICO $<1 \%$; IC1 $\geq 1 \%$ but $<5 \%$; IC $2 / 3 \geq 5 \%$ ) was related to objective response rate (ORR). ORRs were $26 \%$ in the IC $2 \beta$ group, $18 \%$ in the IC $1 / 2 / 3$ group and $15 \%$ in all 310 patients. Moreover a link between response to atezolizumab and intrinsic molecular subtypes of bladder cancer according to The Cancer Genome Atlas (TCGA) classification was described. Response to atezolizumab occurred in all TCGA subtypes, but was significantly higher in the luminal cluster II subtype (ORR 34\%) compared to other subtypes (10\% for subtype I, $16 \%$ for subtype III and $20 \%$ for subtype IV) [67].

Clinical trials testing targeted therapies and immune checkpoints inhibitors in neoadjuvant setting are shown in Table 2. 


\section{Discussion}

The standard of care for MIBC should combine cisplatin-based chemotherapy followed by radical cystectomy with extended pelvic lymph node dissection. Complete PR is the most important favourable prognostic factor correlating with better outcome after surgery; it can be easily determined after cystectomy following 3-4 cycles of NC [68]. Unfortunately, only approximately a third of patients achieve such a response [5]. Therefore the identification of predictive factors of response is an urgent unmet need, to avoid chemotherapy toxicity and surgery delay in non responders. Few existing clinical-pathological tools have been used to identify patients at high risk of progression that could benefit from NC. Culp et al. developed a risk stratification model according to the presence of CT3b-T4a disease, hydroureteronephrosis and/or histological evidence of lymphovascular invasion, neuroendocrine or micropapillary features. High risk patients showed lower 5-year OS (47.0\% vs $64.8 \%)$ and lower disease specific (64.3\% vs $83.5 \%$ ) and progression-free $(62.0 \%$ vs $84.1 \%)$ survival $(p<0.001)$ [69].

NC treated MIBC patients represent an ideal research setting to study resistance mechanisms and treatment response and to identify biomarkers predictive of response. Residual tumors after NC indeed may provide a valuable resource to compare with pre-treatment tumor tissue in order to analyse morphological and molecular features of resistant and responsive cellular clones.

Defects in repair of DNA damage induced by treatment represent an important mechanism of cytotoxic chemotherapy sensitivity. In particular cisplatin, the cornerstone of NC, is an alkylating agent able to cause DNA fragmentation, to induce mutations in nucleotides and to inhibit DNA synthesis via DNA cross-linking. Several studies support the role of some DNA-repair genes, such as BRCA1, ERCC1, ATM, RB1, FANCC and RRM1, as biomarkers of NC sensitivity [25-29, 35].

These studies showed a better response in patients with an higher number of alterations in DNArepair genes [30,35], probably due to DNA damage accumulation.

Furthermore some retrospective studies suggested that alterations in ERCC2 enhance cisplatin sensitivity $[30,31]$ and ERBB2 missense mutations seem to be more frequent in patients responding to NC [31].

Considering these data, DNA-repair genes mutations and missense mutations of ERCC2 and ERBB2/NEU pathway may be considered potential predictive biomarkers of response to cisplatinbased chemotherapy. Unfortunately these biomarkers cannot yet be used to select patients who benefit from NC. All the studies testing the role of these factors as markers of treatment response 
have important limitations as the small number of patients and the heterogeneity of chemotherapy regimens.

These candidate biomarkers require future validation in large prospective studies comparing NC treated patients with patients receiving only surgery to better understand if they have a role as predictive factors or only prognostic.

NC has a unique strength. The comparison between pretreatment transurethral resection of bladder tumor (TURB) specimen and residual neoplastic tissue allows to study pathological and molecular characteristics of treatment-resistant cellular clones, in order to identify pathways responsible of treatment resistance. These pathways can be potential targets for new agents.

Several studies have examined the prognostic significance of alterations in p53 and other cell-cycle regulatory proteins in bladder cancer [15]. Even though there are conflicting reports about the link between p53 status and chemo-sensitivity, some authors suggested that altered expression of p53 may be associated to chemotherapy resistance $[13,17-19]$.

Recent studies have shown the potential of multivariated gene expression models, developed using in vitro-based approach [45] or using microarray sets from tumors of human patients [39, 40], to predict tumor response to chemotherapy.

Although these intriguing results suggest that genetic features can be used to select patients responding to NC, these data have not yet translated into clinically predictive models useful to personalise bladder cancer therapy.

Recently the TGCA Research Network completed a genomic characterization of 131 MIBC founding recurrent "driver" mutations in 32 genes involved in kinase signalling pathways, chromatin and cell-cycle regulation [70]. These data were updated in 2015 [71] and allowed the identification of 4 main molecular clusters.

Likewise, other studies identified 3 clinically relevant molecular subtypes associated with different patients outcome and with different sensitivity to cytotoxic chemotherapy [50,51].

The study of histopathological and molecular features of each subtype will provide in the future important information on mechanisms that underlie treatment response or resistance.

Alteration in tyrosine kinase receptors, intracellular signalling pathways, such as the $\mathrm{PI3K} / \mathrm{AKT} / \mathrm{mTOR}$ pathway $[72,73]$, cell-cycle regulators, chromatin remodelling, and immune mediator [74], are significant in disease progression in bladder cancer, [75] and therapies targeting many of these alterations are currently under study. The majority of these agents demonstrated, 
however, only modest activity [76]. This could be due to the complexity of the molecular signalling pathway implicated in bladder cancer and to the need of better selecting patients.

Among receptor tyrosine kinase-targeted therapies, small molecule pan-FGFR inhibitors, have demonstrated encouraging results in bladder cancer patients harbouring activating FGFR mutations or translocations [77]. In patients with ERBB2 overexpression, preclinical results with trastuzumab conjugated with DM1 (derivate of maytansine 1) (T-DM1), are promising [78].

Others trials are currently ongoing to study the efficacy of inhibitors of cell-cycle regulators, such as Aurora kinase [79] and CDK4 [80] in combination with chemotherapy, and mTOR pathway inhibitors in combination with MEK inhibitors.

Finally, considering the recent significant results of immunotherapy in bladder cancer, new treatment endpoints can be useful in this setting [67]. The anticancer immune response is a complex process that we can easily investigate in neoadjuvant setting in order to identify innovative predictive factors of response to immunological drugs.

In conclusion cisplatin-based NC before cystectomy is the standard of care for MIBC, with 25-50\%

of patients expected to achieve a PR. Despite intriguing evidence suggesting that genetic and molecular characteristics can allow to identify patients likely to benefit from NC, these data have not yet translated into clinically useful tools. Many efforts have been and are continuing to be made to identify and validate predictive biomarkers of response to NC.

\section{References}

[1] Stein JP, Lieskovsky G, Cote R, Groshen S, Feng AC, Boyd S, et al. Radical cystectomy in the treatment of invasive bladder cancer: long-term results in 1,054 patients. J Clin Oncol. 2001;19:666-75.

[2] Bladder Cancer. NCCN Clinical Practice Guidelines in Oncology.Version 2.2015.

[3] Witjes JA CE, Cowan NC, De Santis M, Gakis G, James N, Lebrét T, et al. Guidelines on Muscle-invasive and Metastatic Bladder Cancer European Association of Urology. 2015.

[4] David KA, Milowsky MI, Ritchey J, Carroll PR, Nanus DM. Low incidence of perioperative chemotherapy for stage III bladder cancer 1998 to 2003: a report from the National Cancer Data Base. The Journal of urology. 2007;178:451-4.

[5] Grossman HB, Natale RB, Tangen CM, Speights VO, Vogelzang NJ, Trump DL, et al. Neoadjuvant chemotherapy plus cystectomy compared with cystectomy alone for locally advanced bladder cancer. The New England journal of medicine. 2003;349:859-66.

[6] International Collaboration of T, Medical Research Council Advanced Bladder Cancer Working P, European Organisation for R, Treatment of Cancer Genito-Urinary Tract Cancer G, Australian Bladder Cancer Study G, National Cancer Institute of Canada Clinical Trials G, et al. International phase III trial assessing neoadjuvant cisplatin, methotrexate, and vinblastine chemotherapy for muscle-invasive bladder cancer: long-term results of the BA06 30894 trial. J Clin Oncol.

2011;29:2171-7. 
[7] Advanced Bladder Cancer Meta-analysis C. Neoadjuvant chemotherapy in invasive bladder cancer: a systematic review and meta-analysis. Lancet. 2003;361:1927-34.

[8] Advanced Bladder Cancer Meta-analysis C. Neoadjuvant chemotherapy in invasive bladder cancer: update of a systematic review and meta-analysis of individual patient data advanced bladder cancer (ABC) meta-analysis collaboration. European urology. 2005;48:202-5; discussion 5-6.

[9] Neoadjuvant cisplatin, methotrexate, and vinblastine chemotherapy for muscle-invasive bladder cancer: a randomised controlled trial. International collaboration of trialists. Lancet. 1999;354:53340.

[10] von der Maase H, Hansen SW, Roberts JT, Dogliotti L, Oliver T, Moore MJ, et al. Gemcitabine and cisplatin versus methotrexate, vinblastine, doxorubicin, and cisplatin in advanced or metastatic bladder cancer: results of a large, randomized, multinational, multicenter, phase III study. J Clin Oncol. 2000;18:3068-77.

[11] Apolo AB, Kim JW, Bochner BH, Steinberg SM, Bajorin DF, Kelly WK, et al. Examining the management of muscle-invasive bladder cancer by medical oncologists in the United States. Urologic oncology. 2014;32:637-44.

[12] Dash A, Pettus JAt, Herr HW, Bochner BH, Dalbagni G, Donat SM, et al. A role for neoadjuvant gemcitabine plus cisplatin in muscle-invasive urothelial carcinoma of the bladder: a retrospective experience. Cancer. 2008;113:2471-7.

[13] Plimack ER, Hoffman-Censits JH, Viterbo R, Trabulsi EJ, Ross EA, Greenberg RE, et al. Accelerated methotrexate, vinblastine, doxorubicin, and cisplatin is safe, effective, and efficient neoadjuvant treatment for muscle-invasive bladder cancer: results of a multicenter phase II study with molecular correlates of response and toxicity. J Clin Oncol. 2014;32:1895-901.

[14] Choueiri TK, Jacobus S, Bellmunt J, Qu A, Appleman LJ, Tretter C, et al. Neoadjuvant dosedense methotrexate, vinblastine, doxorubicin, and cisplatin with pegfilgrastim support in muscleinvasive urothelial cancer: pathologic, radiologic, and biomarker correlates. J Clin Oncol. 2014;32:1889-94.

[15] Esrig D, Elmajian D, Groshen S, Freeman JA, Stein JP, Chen SC, et al. Accumulation of nuclear p53 and tumor progression in bladder cancer. The New England journal of medicine. 1994;331:1259-64.

[16] Chang FL, Lai MD. Various forms of mutant p53 confer sensitivity to cisplatin and doxorubicin in bladder cancer cells. The Journal of urology. 2001;166:304-10.

[17] Qureshi KN, Griffiths TR, Robinson MC, Marsh C, Roberts JT, Hall RR, et al. TP53 accumulation predicts improved survival in patients resistant to systemic cisplatin-based chemotherapy for muscle-invasive bladder cancer. Clinical cancer research : an official journal of the American Association for Cancer Research. 1999;5:3500-7.

[18] Kakehi Y, Ozdemir E, Habuchi T, Yamabe H, Hashimura T, Katsura Y, et al. Absence of p53 overexpression and favorable response to cisplatin-based neoadjuvant chemotherapy in urothelial carcinomas. Japanese journal of cancer research : Gann. 1998;89:214-20.

[19] Sarkis AS, Bajorin DF, Reuter VE, Herr HW, Netto G, Zhang ZF, et al. Prognostic value of p53 nuclear overexpression in patients with invasive bladder cancer treated with neoadjuvant MVAC. J Clin Oncol. 1995;13:1384-90.

[20] Cote RJ, Esrig D, Groshen S, Jones PA, Skinner DG. p53 and treatment of bladder cancer. Nature. 1997;385:123-5.

[21] Watanabe J, Nishiyama H, Okubo K, Takahashi T, Toda Y, Habuchi T, et al. Clinical evaluation of p53 mutations in urothelial carcinoma by IHC and FASAY. Urology. 2004;63:989-93. [22] Duggan B, Kelly J, Keane PF, Williamson K, Johnston SR. Bcl-2 expression identifies patients with advanced bladder cancer treated by radiotherapy who benefit from neoadjuvant chemotherapy. BJU international. 2000;86:757.

[23] van Brussel JP, Mickisch GH. Circumvention of multidrug resistance in genitourinary tumors. International journal of urology : official journal of the Japanese Urological Association. 1998;5:115 . 
[24] Cooke PW, James ND, Ganesan R, Burton A, Young LS, Wallace DM. Bcl-2 expression identifies patients with advanced bladder cancer treated by radiotherapy who benefit from neoadjuvant chemotherapy. BJU international. 2000;85:829-35.

[25] Quinn JE, Kennedy RD, Mullan PB, Gilmore PM, Carty M, Johnston PG, et al. BRCA1 functions as a differential modulator of chemotherapy-induced apoptosis. Cancer research. 2003;63:6221-8.

[26] Font A, Taron M, Gago JL, Costa C, Sanchez JJ, Carrato C, et al. BRCA1 mRNA expression and outcome to neoadjuvant cisplatin-based chemotherapy in bladder cancer. Annals of oncology : official journal of the European Society for Medical Oncology / ESMO. 2011;22:139-44.

[27] Bellmunt J, Paz-Ares L, Cuello M, Cecere FL, Albiol S, Guillem V, et al. Gene expression of ERCC1 as a novel prognostic marker in advanced bladder cancer patients receiving cisplatin-based chemotherapy. Annals of oncology : official journal of the European Society for Medical Oncology / ESMO. 2007;18:522-8.

[28] Hoffmann AC, Wild P, Leicht C, Bertz S, Danenberg KD, Danenberg PV, et al. MDR1 and ERCC1 expression predict outcome of patients with locally advanced bladder cancer receiving adjuvant chemotherapy. Neoplasia. 2010;12:628-36.

[29] Olaussen KA, Dunant A, Fouret P, Brambilla E, Andre F, Haddad V, et al. DNA repair by ERCC1 in non-small-cell lung cancer and cisplatin-based adjuvant chemotherapy. The New England journal of medicine. 2006;355:983-91.

[30] Van Allen EM, Mouw KW, Kim P, Iyer G, Wagle N, Al-Ahmadie H, et al. Somatic ERCC2 mutations correlate with cisplatin sensitivity in muscle-invasive urothelial carcinoma. Cancer discovery. 2014;4:1140-53.

[31] Groenendijk FH, de Jong J, Fransen van de Putte EE, Michaut M, Schlicker A, Peters D, et al. ERBB2 Mutations Characterize a Subgroup of Muscle-invasive Bladder Cancers with Excellent Response to Neoadjuvant Chemotherapy. European urology. 2016;69:384-8.

[32] Liu D, Plimack ER, Hoffman-Censits J, Garraway LA, Bellmunt J, Van Allen E, et al. Clinical Validation of Chemotherapy Response Biomarker ERCC2 in Muscle-Invasive Urothelial Bladder Carcinoma. JAMA oncology. 2016;2:1094-6.

[33] Balar A.V. IG, Milowsky M.I., Huang W.C. Multicenter prospective phase II trial of neoadjuvant (neo) dose dense gemcitabine and cisplatin (DD-GC) in patients (pts) with muscleinvasive bladder cancer (MIBC). J Clin Oncol. 2016;34:suppl 2S; abstr 436.

[34] Iyer G, Balar, A.V.,Milowsky, M.I. Correlation of DNA damage response (DDR) gene alterations with response to neoadjuvant (neo) dose-dense gemcitabine and cisplatin (ddGC) in urothelial carcinoma (UC). J Clin Oncol. 2016;34:suppl; abstr 5011.

[35] Plimack ER, Dunbrack RL, Brennan TA, Andrake MD, Zhou Y, Serebriiskii IG, et al. Defects in DNA Repair Genes Predict Response to Neoadjuvant Cisplatin-based Chemotherapy in Muscleinvasive Bladder Cancer. European urology. 2015;68:959-67.

[36] Plimack E.R H-CJH, Kutikov A, Greenberg R.E, Bilusic M, Chen D.Y, Viterbo R, Lallas C.D, Lin J, Trabulsi E.J, Geynisman D.M, Kelly W.K, Smaldone M.C, Devarajan K, Adaire-Halenda B, Cione C, Kilpatrick D, Duncan G, Wong Y. Neoadjuvant dose-dense gemcitabine and cisplatin (DDGC) in patients (pts) with muscle-invasive bladder cancer (MIBC): Final results of a multicenter phase II study. J Clin Oncol. 2014;32:suppl; abstr 4513.

[37] Mooso BA, Vinall RL, Mudryj M, Yap SA, deVere White RW, Ghosh PM. The role of EGFR family inhibitors in muscle invasive bladder cancer: a review of clinical data and molecular evidence. The Journal of urology. 2015;193:19-29.

[38] Takata R, Katagiri T, Kanehira M, Tsunoda T, Shuin T, Miki T, et al. Predicting response to methotrexate, vinblastine, doxorubicin, and cisplatin neoadjuvant chemotherapy for bladder cancers through genome-wide gene expression profiling. Clinical cancer research : an official journal of the American Association for Cancer Research. 2005;11:2625-36. 
[39] Takata R, Katagiri T, Kanehira M, Shuin T, Miki T, Namiki M, et al. Validation study of the prediction system for clinical response of M-VAC neoadjuvant chemotherapy. Cancer science. 2007;98:113-7.

[40] Kato Y, Zembutsu H, Takata R, Miya F, Tsunoda T, Obara W, et al. Predicting response of bladder cancers to gemcitabine and carboplatin neoadjuvant chemotherapy through genome-wide gene expression profiling. Experimental and therapeutic medicine. 2011;2:47-56.

[41] Gery S, Xie D, Yin D, Gabra H, Miller C, Wang H, et al. Ovarian carcinomas: CCN genes are aberrantly expressed and CCN1 promotes proliferation of these cells. Clinical cancer research : an official journal of the American Association for Cancer Research. 2005;11:7243-54.

[42] Rho SB, Woo JS, Chun T, Park SY. Cysteine-rich 61 (CYR61) inhibits cisplatin-induced apoptosis in ovarian carcinoma cells. Biotechnology letters. 2009;31:23-8.

[43] Okabe M, Szakacs G, Reimers MA, Suzuki T, Hall MD, Abe T, et al. Profiling SLCO and SLC22 genes in the NCI-60 cancer cell lines to identify drug uptake transporters. Molecular cancer therapeutics. 2008;7:3081-91.

[44] Baras AS, Gandhi N, Munari E, Faraj S, Shultz L, Marchionni L, et al. Identification and Validation of Protein Biomarkers of Response to Neoadjuvant Platinum Chemotherapy in Muscle Invasive Urothelial Carcinoma. PloS one. 2015;10:e0131245.

[45] Williams PD, Cheon S, Havaleshko DM, Jeong H, Cheng F, Theodorescu D, et al. Concordant gene expression signatures predict clinical outcomes of cancer patients undergoing systemic therapy. Cancer research. 2009;69:8302-9.

[46] Hendrix ND, Wu R, Kuick R, Schwartz DR, Fearon ER, Cho KR. Fibroblast growth factor 9 has oncogenic activity and is a downstream target of Wnt signaling in ovarian endometrioid adenocarcinomas. Cancer research. 2006;66:1354-62.

[47] Miller LD, Smeds J, George J, Vega VB, Vergara L, Ploner A, et al. An expression signature for p53 status in human breast cancer predicts mutation status, transcriptional effects, and patient survival. Proceedings of the National Academy of Sciences of the United States of America. 2005;102:13550-5.

[48] Wu Z, Siadaty MS, Riddick G, Frierson HF, Jr., Lee JK, Golden W, et al. A novel method for gene expression mapping of metastatic competence in human bladder cancer. Neoplasia. 2006;8:181-9.

[49] Dinney CP, Hansel D, McConkey D, Shipley W, Hagan M, Dreicer R, et al. Novel neoadjuvant therapy paradigms for bladder cancer: results from the National Cancer Center Institute Forum. Urologic oncology. 2014;32:1108-15.

[50] Lindgren D, Frigyesi A, Gudjonsson S, Sjodahl G, Hallden C, Chebil G, et al. Combined gene expression and genomic profiling define two intrinsic molecular subtypes of urothelial carcinoma and gene signatures for molecular grading and outcome. Cancer research. 2010;70:3463-72.

[51] Choi W, Porten S, Kim S, Willis D, Plimack ER, Hoffman-Censits J, et al. Identification of distinct basal and luminal subtypes of muscle-invasive bladder cancer with different sensitivities to frontline chemotherapy. Cancer cell. 2014;25:152-65.

[52] Kilari D, Iczkowski KA, Pandya C, Robin AJ, Messing EM, Guancial E, et al. Copper Transporter-CTR1 Expression and Pathological Outcomes in Platinum-treated Muscle-invasive Bladder Cancer Patients. Anticancer Res. 2016;36:495-501.

[53] Petrylak DP, Scher HI, Reuter V, O'Brien JP, Cordon-Cardo C. P-glycoprotein expression in primary and metastatic transitional cell carcinoma of the bladder. Annals of oncology : official journal of the European Society for Medical Oncology / ESMO. 1994;5:835-40.

[54] Afonso J, Santos LL, Miranda-Goncalves V, Morais A, Amaro T, Longatto-Filho A, et al. CD147 and MCT1-potential partners in bladder cancer aggressiveness and cisplatin resistance. Molecular carcinogenesis. 2015;54:1451-66.

[55] Als AB, Dyrskjot L, von der Maase H, Koed K, Mansilla F, Toldbod HE, et al. Emmprin and survivin predict response and survival following cisplatin-containing chemotherapy in patients with 
advanced bladder cancer. Clinical cancer research : an official journal of the American Association for Cancer Research. 2007;13:4407-14.

[56] Moscow JA, Dixon KH. Glutathione-related enzymes, glutathione and multidrug resistance. Cytotechnology. 1993;12:155-70.

[57] Pendyala L, Velagapudi S, Toth K, Zdanowicz J, Glaves D, Slocum H, et al. Translational studies of glutathione in bladder cancer cell lines and human specimens. Clinical cancer research : an official journal of the American Association for Cancer Research. 1997;3:793-8.

[58] Siu LL, Banerjee D, Khurana RJ, Pan X, Pflueger R, Tannock IF, et al. The prognostic role of p53, metallothionein, P-glycoprotein, and MIB-1 in muscle-invasive urothelial transitional cell carcinoma. Clinical cancer research : an official journal of the American Association for Cancer Research. 1998;4:559-65.

[59] Chaudhary U. B GAR, Brisendine A., Kraft A. S. . Phase II trial of neoadjuvant cisplatin, gemcitabine, and bevacizumab followed by radical cystectomy (RC) in patients with muscleinvasive transitional cell carcinoma (TCC) of the bladder. J Clin Oncol. 2011;29:suppl 7; abstr 276. [60] Siefker-Radtke A. O. KAM, Corn P.G., Matin S.F. Neoadjuvant chemotherapy with DDMVAC and bevacizumab in high-risk urothelial cancer: Results from a phase II trial at the M. D. Anderson Cancer Center. J Clin Oncol. 2012;30:suppl 5; abstr 261.

[61] Galsky MD, Hahn NM, Powles T, Hellerstedt BA, Lerner SP, Gardner TA, et al. Gemcitabine, Cisplatin, and sunitinib for metastatic urothelial carcinoma and as preoperative therapy for muscleinvasive bladder cancer. Clinical genitourinary cancer. 2013;11:175-81.

[62] Balar A.V IG, Apolo A.B, Regazzi A.M, Garcia-Grossman I.R, Pendse D, Ostrovnaya I, Chou J.F, Bochner B, Dalbagni G, Herr H.W, Milowsky M.I, Bajorin D.F. Phase II trial of neoadjuvant gemcitabine $(\mathrm{G})$ and cisplatin $(\mathrm{C})$ with sunitinib in patients (pts) with muscle-invasive bladder cancer (MIBC). J Clin Oncol. 2012;30:4581.

[63] Pruthi RS, Nielsen M, Heathcote S, Wallen EM, Rathmell WK, Godley P, et al. A phase II trial of neoadjuvant erlotinib in patients with muscle-invasive bladder cancer undergoing radical cystectomy: clinical and pathological results. BJU international. 2010;106:349-54.

[64] Hahn NM, Knudsen BS, Daneshmand S, Koch MO, Bihrle R, Foster RS, et al. Neoadjuvant dasatinib for muscle-invasive bladder cancer with tissue analysis of biologic activity. Urologic oncology. 2016;34:4 e11-7.

[65] Narayan V, Mamtani R, Keefe S, Guzzo T, Malkowicz SB, Vaughn DJ. Cisplatin, Gemcitabine, and Lapatinib as Neoadjuvant Therapy for Muscle-Invasive Bladder Cancer. Cancer research and treatment : official journal of Korean Cancer Association. 2016 Jul;48(3):1084-91.

[66] Carthon BC, Wolchok JD, Yuan J, Kamat A, Ng Tang DS, Sun J, et al. Preoperative CTLA-4 blockade: tolerability and immune monitoring in the setting of a presurgical clinical trial. Clinical cancer research : an official journal of the American Association for Cancer Research.

2010;16:2861-71.

[67] Rosenberg JE, Hoffman-Censits J, Powles T, van der Heijden MS, Balar AV, Necchi A, et al. Atezolizumab in patients with locally advanced and metastatic urothelial carcinoma who have progressed following treatment with platinum-based chemotherapy: a single-arm, multicentre, phase 2 trial. Lancet. 2016;387:1909-20.

[68] Sonpavde G, Goldman BH, Speights VO, Lerner SP, Wood DP, Vogelzang NJ, et al. Quality of pathologic response and surgery correlate with survival for patients with completely resected bladder cancer after neoadjuvant chemotherapy. Cancer. 2009;115:4104-9.

[69] Culp SH, Dickstein RJ, Grossman HB, Pretzsch SM, Porten S, Daneshmand S, et al. Refining patient selection for neoadjuvant chemotherapy before radical cystectomy. The Journal of urology. 2014;191:40-7.

[70] Network CGAR. Comprehensive molecular characterization of urothelial bladder carcinoma. Nature. 2015;507:315-22. 
[71] Kim J, Akbani R, Creighton CJ, Lerner SP, Weinstein JN, Getz G, et al. Invasive Bladder Cancer: Genomic Insights and Therapeutic Promise. Clinical cancer research : an official journal of the American Association for Cancer Research. 2015;21:4514-24.

[72] Fahmy M, Mansure JJ, Brimo F, Yafi FA, Segal R, Althunayan A, et al. Relevance of the mammalian target of rapamycin pathway in the prognosis of patients with high-risk non-muscle invasive bladder cancer. Human pathology. 2013;44:1766-72.

[73] Gonzalez-Roibon ND, Chaux A, Al-Hussain T, Osunkoya AO, Bezerra SM, Hicks J, et al. Dysregulation of mammalian target of rapamycin pathway in plasmacytoid variant of urothelial carcinoma of the urinary bladder. Human pathology. 2013;44:612-22.

[74] Powles T, Eder JP, Fine GD, Braiteh FS, Loriot Y, Cruz C, et al. MPDL3280A (anti-PD-L1) treatment leads to clinical activity in metastatic bladder cancer. Nature. 2014;515:558-62.

[75] Netto GJ, Tafe LJ. Emerging Bladder Cancer Biomarkers and Targets of Therapy. The Urologic clinics of North America. 2016;43:63-76.

[76] Seront E, Machiels JP. Molecular biology and targeted therapies for urothelial carcinoma. Cancer treatment reviews. 2015;41:341-53.

[77] Tabernero J, Bahleda R, Dienstmann R, Infante JR, Mita A, Italiano A, et al. Phase I DoseEscalation Study of JNJ-42756493, an Oral Pan-Fibroblast Growth Factor Receptor Inhibitor, in Patients With Advanced Solid Tumors. J Clin Oncol. 2015;33:3401-8.

[78] Hayashi T, Seiler R, Oo HZ, Jager W, Moskalev I, Awrey S, et al. Targeting HER2 with TDM1, an Antibody Cytotoxic Drug Conjugate, is Effective in HER2 Over Expressing Bladder Cancer. The Journal of urology. 2015;194:1120-31.

[79] Dees EC, Cohen RB, von Mehren M, Stinchcombe TE, Liu H, Venkatakrishnan K, et al. Phase I study of aurora A kinase inhibitor MLN8237 in advanced solid tumors: safety, pharmacokinetics, pharmacodynamics, and bioavailability of two oral formulations. Clinical cancer research : an official journal of the American Association for Cancer Research. 2012;18:4775-84.

[80] Lin CC, Su WC, Yen CJ, Hsu CH, Su WP, Yeh KH, et al. A phase I study of two dosing schedules of volasertib (BI 6727), an intravenous polo-like kinase inhibitor, in patients with advanced solid malignancies. Br J Cancer. 2014;110:2434-40. 
Table 1. Biomarkers and gene expression models predictive of response to neoadjuvant chemotherapy for muscle-invasive bladder cancer

\begin{tabular}{|c|c|c|c|c|c|c|}
\hline \multicolumn{7}{|c|}{ Biomarkers predictive of response to NC } \\
\hline Biomarkers & $\begin{array}{c}\text { Author, year } \\
\text { (ref) }\end{array}$ & Setting & Chemotherapy & Patients (N) & Methods & Main results \\
\hline \multirow{5}{*}{ P53 } & $\begin{array}{l}\text { Plimack, } \\
2014[13]\end{array}$ & $\begin{array}{l}\text { CT2-T4a and NO- } \\
\text { N1 MIBC }\end{array}$ & Accelerated MVAC & 39 & $\begin{array}{l}\text { DNA } \\
\text { sequencing } \\
\text { (Illumina) }\end{array}$ & $\begin{array}{l}\text { No correlation between altered } \mathrm{p} 53 \text { and response to } \\
\text { NC }\end{array}$ \\
\hline & $\begin{array}{l}\text { Qureshi, } \\
1999[17]\end{array}$ & $\begin{array}{l}\text { Non-metastatic } \\
\text { MIBC }\end{array}$ & $\begin{array}{l}\text { CM or CME or CMV } \\
\text { or MVAC }\end{array}$ & 83 & IHC & $\begin{array}{l}\text { No correlation between P53 immunopositivity and } \\
\text { response to NC }\end{array}$ \\
\hline & $\begin{array}{l}\text { Watanabe, } \\
2004[21]\end{array}$ & $\begin{array}{l}\text { Non-metastatic } \\
\text { MIBC }\end{array}$ & CME or CMA & 13 & $\begin{array}{l}\text { FASAY, IHC, } \\
\text { and } \\
\text { sequencing } \\
\text { analysis }\end{array}$ & $\begin{array}{l}\text { Six }(85.7 \%) \text { of } 7 \text { responders to } N C \text { harbored } p 53 \\
\text { missense mutations in at least one allele }(p=0.01)\end{array}$ \\
\hline & $\begin{array}{l}\text { Kakehi, } 1998 \\
{[18]}\end{array}$ & $\begin{array}{l}\text { Non-metastatic } \\
\text { MIBC }\end{array}$ & $\begin{array}{l}\text { MVAC or CME or } \\
\text { CMA or }\end{array}$ & 32 & IHC & $\begin{array}{l}\text { The responsiveness to NC was correlated with } p 53- \\
\text { negative staining status }(p=0.0225)\end{array}$ \\
\hline & $\begin{array}{l}\text { Sarkis, } 1995 \\
{[19]}\end{array}$ & $\begin{array}{l}\text { Non-metastatic } \\
\text { MIBC }\end{array}$ & MVAC & 111 & IHC & $\begin{array}{l}\text { p53 overexpression had independent significance for } \\
\text { survival ( } p=0.001 \text {; relative risk ratio, } 3.1 \text { ) }\end{array}$ \\
\hline $\mathrm{Bcl}-2$ & $\begin{array}{l}\text { Duggan, } \\
2000[22]\end{array}$ & $\begin{array}{l}\text { T2-T4 NXMO } \\
\text { TCC of the } \\
\text { bladder }\end{array}$ & $\begin{array}{l}\text { Cisplatin } 100 \\
\mathrm{mg} / \mathrm{mq} \text { every } 3 \\
\text { weeks }\end{array}$ & 51 & IHC & $\begin{array}{l}\mathrm{BCL}-2 \text { negative patients receiving } \mathrm{NC} \text { had a better } \\
\text { prognosis, median survival: } 72 \text { vs } 17 \text { months }\end{array}$ \\
\hline BRCA1 & $\begin{array}{l}\text { Font ,2011 } \\
{[26]}\end{array}$ & $\begin{array}{l}\text { Non-metastatic } \\
\text { MIBC }\end{array}$ & $\mathrm{CMV}$ or $\mathrm{GC}$ & 57 & PCR & $\begin{array}{l}60 \% \text { of patients with low/intermediate BRCA1 levels } \\
\text { atteined PR (T0-T1) vs } 22 \% \text { of those with high levels }\end{array}$ \\
\hline ERCC1 & $\begin{array}{l}\text { Choueri, } \\
2014[14]\end{array}$ & $\begin{array}{l}\text { Non-metastatic } \\
\text { MIBC }\end{array}$ & Dose-dense MVAC & 31 & $\mathrm{IHC}$ & $\begin{array}{l}\text { 43\% of ERCC1-positive and } 60 \% \text { of ERCC1-negative } \\
\text { patients achieved complete PR }\end{array}$ \\
\hline \multirow{3}{*}{ ERCC2 } & $\begin{array}{l}\text { Van Allen, } \\
2014[30]\end{array}$ & $\begin{array}{l}\text { Non-metastatic } \\
\text { MIBC }\end{array}$ & $\begin{array}{l}\text { GC or dose-dense } \\
\text { MVAC or dose- } \\
\text { dense GC or GC } \\
\text { and sunitinib }\end{array}$ & $\begin{array}{l}50(25 \\
\text { responders } \\
\text { and } 25 \text { non- } \\
\text { responders }\end{array}$ & $\begin{array}{l}\text { Whole exome } \\
\text { sequencing }\end{array}$ & $\begin{array}{l}\text { ERCC2 was the only significantly mutated gene } \\
\text { enriched in the cisplatin responders compared with } \\
\text { non-responders }(p<0.01)\end{array}$ \\
\hline & $\begin{array}{l}\text { Liu, } 2016 \\
\text { [32] }\end{array}$ & $\begin{array}{l}\text { Non-metastatic } \\
\text { MIBC }\end{array}$ & Platinum-based & 62 & $\begin{array}{l}\text { Whole exome } \\
\text { sequencing }\end{array}$ & $\begin{array}{l}\text { Nonsynonymous ERCC2 mutations were identified in } \\
7 \% \text { of non-responders and in } 40 \% \text { of responders odds } \\
\text { ratio: } 8.3 ; 95 \% \mathrm{Cl}: 1.4-91.4 ; \mathrm{p}=0.01) \text {. }\end{array}$ \\
\hline & Groenendijk, & Non-metastatic & MVAC or GC or & $71(38$ & NGS of 178 & ERCC2 missense mutations were more common in \\
\hline
\end{tabular}




\begin{tabular}{|c|c|c|c|c|c|c|}
\hline \multirow[b]{2}{*}{ ERBB2 } & \multirow[t]{2}{*}{2016 [31] } & \multirow[t]{2}{*}{ MIBC } & \multirow[t]{2}{*}{$\begin{array}{l}\text { gemcitabine- } \\
\text { carboplatin }\end{array}$} & \multirow{2}{*}{$\begin{array}{l}\text { responders } \\
\text { and } 33 \text { non- } \\
\text { responders }\end{array}$} & \multirow{2}{*}{$\begin{array}{l}\text { cancer- } \\
\text { associated } \\
\text { genes }\end{array}$} & $\begin{array}{l}\text { patients atteined complete } P R \text {, but not reaching } \\
\text { statistical significance }\end{array}$ \\
\hline & & & & & & $\begin{array}{l}9 \text { of } 38 \text { complete responders vs } 0 \text { of } 33 \text { non- } \\
\text { responders had ERBB2 missense mutations ( } p=0.003 \text { ) }\end{array}$ \\
\hline $\begin{array}{l}\text { ATM, RB and } \\
\text { FANCC }\end{array}$ & $\begin{array}{l}\text { Plimack, } \\
2015[35]\end{array}$ & $\begin{array}{l}\text { Non-metastatic } \\
\text { MIBC }\end{array}$ & $\begin{array}{l}\text { Discovery cohort: } \\
\text { accelerated MVAC } \\
\text { Validation cohort: } \\
\text { dose-dense GC }\end{array}$ & $\begin{array}{l}\text { Discovery } \\
\text { cohort: } 34 \\
\text { Validation } \\
\text { cohort: } 24\end{array}$ & $\begin{array}{l}\text { Sequencing of } \\
287 \text { cancer- } \\
\text { related genes }\end{array}$ & $\begin{array}{l}\text { ATM,RB1 and FANCC alterations were related to PR in } \\
\text { both the discovery }(p<0.001) \text { and validation set } \\
(p=0.033)\end{array}$ \\
\hline $\begin{array}{l}\text { MCT1 and } \\
\text { CD147 }\end{array}$ & $\begin{array}{l}\text { Afonso, } 2015 \\
{[54]}\end{array}$ & $\begin{array}{l}\text { Non-metastatic } \\
\text { MIBC }\end{array}$ & $\begin{array}{l}\text { Platinum-based } \\
\text { chemotherapy }\end{array}$ & 31 & IHC & $\begin{array}{l}\text { Prognosis was worse in patients with MCT1 or CD147 } \\
\text { positive tumors; OS: } 42.2 \text { vs } 12.4 \text { months }(p=0.026)\end{array}$ \\
\hline CTR-1 & $\begin{array}{l}\text { Kilari, } 2016 \\
{[52]}\end{array}$ & MIBC & Platinum-based & 47 & IHC & $\begin{array}{l}\text { Higher CTR- } 1 \text { expression score correlated with } \\
\text { pathologicalresponse (both in pre-NC specimens: } \\
p=0.0076 \text { and in post NC specimens, } p=0.023 \text { ) }\end{array}$ \\
\hline $\begin{array}{l}\text { Molecular } \\
\text { subtypes: } \\
\text { basal-like, } \\
\text { luminal-like } \\
\text { and p53-like }\end{array}$ & $\begin{array}{l}\text { Choi, } 2014 \\
{[51]}\end{array}$ & MIBC & Platinum-based & 73 & $\begin{array}{l}\text { Whole } \\
\text { genome } \\
\text { mRNA } \\
\text { expression } \\
\text { profiling }\end{array}$ & $\begin{array}{l}\text { Response to NC was } 0 \% \text { in } p 53-\text {-like, } 40 \% \text { in basal-like } \\
\text { and } 67 \% \text { in luminal-like subtype }(p=0.018) \text {. }\end{array}$ \\
\hline \multicolumn{7}{|c|}{ Gene expression models predictive of response to NC } \\
\hline GEM & Author, year & Setting & Chemotherapy & Patients & Methods & Mainresults \\
\hline \multirow{2}{*}{$\begin{array}{l}\text { Numerical } \\
\text { prediction } \\
\text { scoring } \\
\text { system } \\
\text { including } 14 \\
\text { genes }\end{array}$} & $\begin{array}{l}\text { Takata, } 2005 \\
{[38]}\end{array}$ & $\begin{array}{l}\text { TCC bladder } \\
\text { cancer }\end{array}$ & MVAC & $\begin{array}{l}18 \text { (9 } \\
\text { responders } \\
\text { and } 9 \text { non- } \\
\text { responders) }\end{array}$ & \multirow{2}{*}{$\begin{array}{l}\text { Genome-wide } \\
\text { expression } \\
\text { profiling using } \\
\text { a microarray } \\
\text { including } \\
27648 \text { genes }\end{array}$} & $\begin{array}{l}14 \text { gene separated the responders from non- } \\
\text { responder group. Among these genes Topoisomerase } \\
2 \text {, was downregulated in non-responder group. The } \\
\text { scoring system correctly identified response for } 8 \text { of } 9 \\
\text { cases }\end{array}$ \\
\hline & $\begin{array}{l}\text { Takata, } 2007 \\
{[39]}\end{array}$ & $\begin{array}{l}\text { TCC bladder } \\
\text { cancer }\end{array}$ & MVAC & 22 & & $\begin{array}{l}\text { The scoring system correctly identified response for } \\
19 \text { of } 22 \text { cases }\end{array}$ \\
\hline $\begin{array}{l}\text { Numerical } \\
\text { prediction } \\
\text { scoring } \\
\text { system } \\
\text { including } 12 \\
\text { genes }\end{array}$ & $\begin{array}{l}\text { Kato, } 2011 \\
{[40]}\end{array}$ & $\begin{array}{l}\text { T2a-T4a NO M0 } \\
\text { TCC bladder } \\
\text { cancer }\end{array}$ & $\begin{array}{l}\text { Carboplatin and } \\
\text { gemcitabine }\end{array}$ & $\begin{array}{l}\text { Discovery } \\
\text { cohort: } 18 \text { (9 } \\
\text { responders } \\
\text { and } 9 \text { non- } \\
\text { responders) } \\
\text { Validation } \\
\text { cohort: } 19\end{array}$ & $\begin{array}{l}\text { Genome-wide } \\
\text { expression } \\
\text { profiling using } \\
\text { a microarray } \\
\text { including } \\
28500 \text { genes }\end{array}$ & $\begin{array}{l}12 \text { genes separated responders ( } 9 \text { patients) from } \\
\text { non-responders ( } 9 \text { patients). Among these genes IPO- } \\
7 \text { and SLC22A18 were up-regulated in non- } \\
\text { responders. The scoring system correctly identified } \\
\text { response for } 18 \text { of } 19 \text { cases in the validation cohort }\end{array}$ \\
\hline
\end{tabular}




\begin{tabular}{|l|l|l|l|l|l|l|}
\hline $\begin{array}{l}\text { Protein } \\
\text { based } \\
\text { predictive } \\
\text { model }\end{array}$ & $\begin{array}{l}\text { Baras, 2015 } \\
{[44]}\end{array}$ & $\begin{array}{l}\text { T2a-T4a N0 M0 } \\
\text { TCC bladder } \\
\text { cancer }\end{array}$ & $\begin{array}{l}\text { Carboplatin and } \\
\text { gemcitabine }\end{array}$ & 37 & IHC & $\begin{array}{l}\text { The combination of GDPD3 and SPRED1 resulted in a } \\
\text { multivariate classification tree that was significantly } \\
\text { associated with NC response (p<0.0001) }\end{array}$ \\
\hline $\begin{array}{l}\text { In vitro- } \\
\text { based GEM }\end{array}$ & $\begin{array}{l}\text { Williams, } \\
2009[45]\end{array}$ & $\begin{array}{l}\text { Non-metastatic } \\
\text { MIBC }\end{array}$ & MVAC & 59 & $\begin{array}{l}\text { In vitro drug } \\
\text { sensitivities } \\
\text { evaluation and } \\
\text { microarray } \\
\text { analyses }\end{array}$ & $\begin{array}{l}\text { The 3-years OS for patients with favourable gene } \\
\text { expression model score was } 81 \% \text { vs 33\% for those } \\
\text { with un-favourable score (p=0.002) }\end{array}$ \\
\hline
\end{tabular}

MIBC: muscle-invasive bladder cancer; NC: neoadjuvant chemotherapy; MVAC: methotrexate, vinblastine, adriamycin and cisplatin ; CM: cisplatin and methotrexate; CMV: cisplatin, methotrexate, and vinblastine; CME: Cisplatin, methotrexate, and epirubicin; CMA: cisplatin, methotrexate and adriamycin; IHC: immunohistochemistry; FASAY: yeast functional assay; TCC: transitional cell carcinoma; GC: gemcitabine and cisplatin; PR: pathological response; NGS: nextgeneration sequencing; GEM: gene expression model; OS: overall survival. 
Table 2: Clinical trials of targeted agents or immune checkpoints inhibitors in neoadjuvant setting for urothelial cancer

\begin{tabular}{|c|c|c|c|c|c|c|}
\hline \multicolumn{7}{|c|}{ Reported trials } \\
\hline Author, year (ref) & Phase & Agent & Target & AssociatedChemotherapy & Patients (N) & Outcome \\
\hline Balar, 2012 [62] & ॥ & Sunitinib & $\begin{array}{l}\text { VEGFR type 1-2, PDGFR- } \\
\alpha-\beta, \text { KIT, RET, FLT3, } \\
\text { CSF1R }\end{array}$ & Gemcitabine and cisplatin & 18 & PR rate: $33 \%$ \\
\hline Galsky, 2013 [61] & II & Sunitinib & $\begin{array}{l}\text { VEGFR type 1-2, PDGFR- } \\
\alpha-\beta, \text { KIT, RET, FLT3, } \\
\text { CSF1R }\end{array}$ & Gemcitabine and cisplatin & 9 & PR rate: $22 \%$ \\
\hline $\begin{array}{l}\text { Chaudhary, } 2011 \\
\text { [59] }\end{array}$ & ॥ & Bevacizumab & VEGF & Gemcitabine and cisplatin & 15 & PR rate: $31 \%$ \\
\hline $\begin{array}{l}\text { Siefker-Radtke, } \\
2012 \text { [60] }\end{array}$ & ॥ & Bevacizumab & VEGF & Dose-dense MVAC & 15 & PR rate: $53 \%$ \\
\hline Narayan, 2015 [65] & $\|$ & Lapatinib & EGFR-ERBB2 & Gemcitabine and cisplatin & 6 & PR rate: $17 \%$ \\
\hline Pruthi, 2010 [63] & $\|$ & Erlotinib & EGFR & None & 20 & PR rate: $35 \%$ \\
\hline Hahn, 2012 [64] & ॥ & Dasatinib & $\begin{array}{l}\text { Src family tyrosine } \\
\text { kinase and BCR-ABL }\end{array}$ & None & 25 & PR rate: $14 \%$ \\
\hline Carthon, 2010 [66] & $1 / 11$ & Ipilimumab & CTLA-4 & None & 12 & $\begin{array}{l}\text { Correlation between OS and } \\
\text { increase in CD4+ICOS+ T } \\
\text { cells }\end{array}$ \\
\hline \multicolumn{7}{|c|}{ Ongoing trials } \\
\hline Clinicaltrials.gov ID & Phase & Agent & Target & Associatedchemotherapy & State & \\
\hline NCT01326871 & $1 / 11$ & ALT-801 & p53 & Gemcitabine and cisplatin & $\begin{array}{l}\text { Active, not } \\
\text { recruiting }\end{array}$ & \\
\hline
\end{tabular}




\begin{tabular}{|c|c|c|c|c|c|c|}
\hline NCT02365766 & $1 / 11$ & Pembrolizumab & PD-1 & Gemcitabine and cisplatin & $\begin{array}{l}\text { Active, not } \\
\text { recruiting }\end{array}$ & \\
\hline NCT02451423 & II & MPDL3280A & PD-L1 & None & $\begin{array}{l}\text { Active, not } \\
\text { recruiting }\end{array}$ & \\
\hline NCT02845323 & II & $\begin{array}{l}\text { Nivolumab+/- } \\
\text { Urelumab }\end{array}$ & CD137 receptor & None & $\begin{array}{l}\text { Not yet } \\
\text { recruiting }\end{array}$ & \\
\hline NCT02812420 & $1 / 11$ & $\begin{array}{l}\text { Durvalumab + } \\
\text { Tremelimumab }\end{array}$ & PD-L1, CTLA-4 & None & $\begin{array}{l}\text { Not yet } \\
\text { recruiting }\end{array}$ & \\
\hline NCT00749892 & II & Erlotinib & EGFR & None & $\begin{array}{l}\text { Active, not } \\
\text { recruiting }\end{array}$ & \\
\hline
\end{tabular}




\section{Highlights}

- Neoadjuvant chemotherapy (NC) prolongs OS in muscle-invasive bladder cancer (MIBC)

- Only a third of patients achieve pathological response to NC

- Multiple molecular biomarkers have been studied for prediction of response to NC

- Many efforts have been and are continuing to be made to validate predictive biomarkers of response to NC 


\section{${ }^{*}$ Conflict of Interest Statement}

\section{Disclosures}

We wish to confirm that there are no known conflicts of interest associated with this publication and there has been no significant financial support for this work that could have influenced its outcome.

We confirm that the manuscript has been read and approved by all named authors and that there are no other persons who satisfied the criteria for authorship but are not listed. We further confirm that the order of authors listed in the manuscript has been approved by all of us.

We declare that none of the authors has any conflict of interest to declare.

Giorgio V. Scagliotti

On behalf of all co-authors 